\section{Regulation of Petal Abscission in Pelargonium $\times$ domesticum}

\author{
C. Fred Deneke', Kathleen B. Evensen, and Richard Craig \\ Department of Horticulture, The Pennsylvania State University, \\ University Park, PA 16802
}

Additional index words. regal pelargonium, ethylene, potted flowering plants, postharvest physiology, silver thiosulfate

Abstract. The postharvest quality of regal pelargoniums [Pelargonium $\times$ domesticum L. H. Bailey] is limited by petal abscission. Cultivars that have diverse postharvest longevities were selected to study ethylene sensitivity and endogenous ethylene production. Petals of both intact and detached inflorescences abscised in response to low dosages of exogenous ethylene $\left(0.5 \mu l \cdot l^{-1} r^{-1}\right.$ for 1 hour $)$. Ethylene sensitivity varied among cultivars and increased with floret age. Silver thiosulfate reduced ethylene sensitivity and often extended floret longevity beyond that of the controls. A climactericlike rise in endogenous ethylene production occurred in excised gynoecia (including the receptacle) as floret age increased from 1 to 12 days postanthesis. Ethylene production increased a few days earlier and achieved a higher maximum rate in 'Parisienne' than in 'Virginia'; 'Parisienne' also abscised petals earlier. Relatively low levels of endogenous ethylene may regulate petal abscission, since inflorescences were very sensitive to exogenous ethylene, and increased endogenous ethylene production preceded petal abscission.

The postharvest quality of many flowers is reduced by ethylene, which synchronizes the terminal events of senescence (Nichols, 1984). Ethylene-induced senescence or abscission may result from exposure to exogenous ethylene, or endogenous ethylene

Received for publication 5 July 1989. Contribution no. 133 Dept. of Horticulture. Authorized for publication as paper no. 8029 in the journal series of the Pennsylvania Agricultural Experiment Station. This work was supported in part by the Fred C. Gloeckner Foundation and Oglevee Associates. Mention of a trademark, proprietary product, or vendor does not imply endorsement by The Pennsylvania State Univ., nor criticism of similar ones not mentioned. The cost of publishing this paper was defrayed in part by the payment of page charges. Under postal regulations, this paper therefore must be hereby marked advertisement solely to indicate this fact.

${ }^{1}$ Present address: Dept. of Horticulture, Auburn Univ., AL 36849-5408. Duncan $\mathrm{k}$ ratio $t$ test $(\mathrm{k}=100)$. production may be increased by stress, infection, or pollination (Halevy, 1986; Nichols, 1984). Silver thiosulfate (STS) delays senescence by inhibiting ethylene action (Beyer, 1976). It is effective as a stem dip in many cut flowers and as a spray in several potted flowering plants, including zonal geranium (Cameron and Reid, 1983; Miranda,
1981), zygocactus (Cameron and Reid, 1981), and streptocarpus (Agnew et al., 1985).

The regal pelargonium has great commercial potential as a flowering potted plant because of its large, showy flowers, but it is very susceptible to petal abscission. We investigated the postharvest longevity of detached and intact inflorescences of regal pelargoniums by evaluating their responsiveness to STS and their sensitivity to exogenous ethylene. Since regal pelargoniums proved very sensitive to exogenous ethylene, the rate of endogenous ethylene production by florets was measured and related to petal abscission.

Plant materials. Rooted cuttings from culture virus-indexed propagative stock of regal pelargoniums were obtained from a commercial propagator (Oglevee Associates, Connellsville, $\mathrm{Pa}$.). Floral initiation had been promoted by exposing the plants to $10 \mathrm{C}$ for 4 weeks. Cuttings that were not so treated were designated as noncooled. Cultivars used were 'Country Girl' (CG), 'Grand Slam' (GS), 'Lavender Grand Slam' (LGS), 'Melissa' (MSA), 'Parisienne' (PRS), and 'Virginia' (VA).

Instrumentation. Air temperatures were measured at mid-shoot height by maximumminimum thermometers (Model 5458, Taylor Scientific Consumer Instruments, Arden, N.C.) and by hygrothermographs (Model 594, Friez/Bendix Co., Baltimore). The hygrothermographs were also used to monitor relative humidity. Photosynthetic photon flux (PPF) was measured at mid-shoot height with

Table 1. Longevity of florets of regal pelargonium cultivars PRS and VA that reached anthesis before (open) or after (bud) the plants were treated with ethylene. Longevity of open florets includes only those florets that did not abscise on the first day after treatment.

\begin{tabular}{ccccc}
\hline \hline \multirow{2}{*}{$\begin{array}{c}\text { Floret stage } \\
\text { at treatment }\end{array}$} & Cultivar & Control & Ethylene & STS + ethylene \\
\cline { 2 - 5 } Open & PRS & $9 \mathrm{~b}^{\mathbf{z}}$ & $9 \mathrm{~b}$ & $10 \mathrm{a}$ \\
& VA & $14 \mathrm{a}$ & $15 \mathrm{a}$ & $15 \mathrm{a}$ \\
Bud & PRS & $8 \mathrm{c}$ & $10 \mathrm{~b}$ & $13 \mathrm{a}$ \\
& VA & $13 \mathrm{a}$ & $13 \mathrm{a}$ & $13 \mathrm{a}$ \\
\hline
\end{tabular}

${ }^{2}$ Means within rows followed by the same letter are not significantly different according to the Waller- 


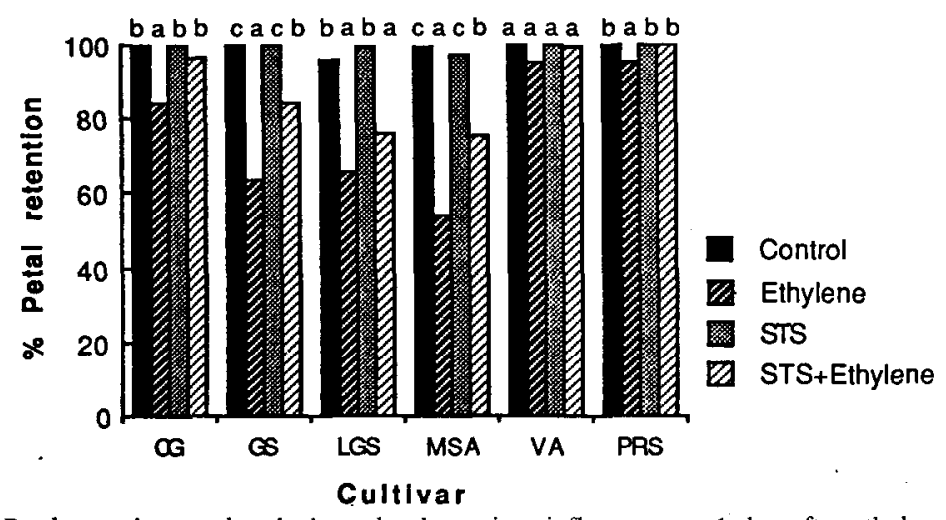

Fig. 1. Petal retention on detached regal pelargonium inflorescenccs 1 day after ethylene exposure $\left(0.5 \mu \mathrm{l} \cdot \mathrm{liter}^{-1}\right.$ for $1 \mathrm{hr}$ at $\left.21 \mathrm{C}\right)$ for control and STS (1 mM at anthesis)-treated inflorescences. In the analysis of variance, cultivar, ethylene, STS, cultivar $\times$ ethylene, and cultivar $\times$ STS $\times$ ethylene were significant at $P<0.01$, while the cultivar $\times$ STS interaction was not significant. Means within cultivars with a common letter are not significantly different according to the Waller-Duncan $\mathrm{k}$ ratio $t$. test $(\mathrm{k}=100)$.
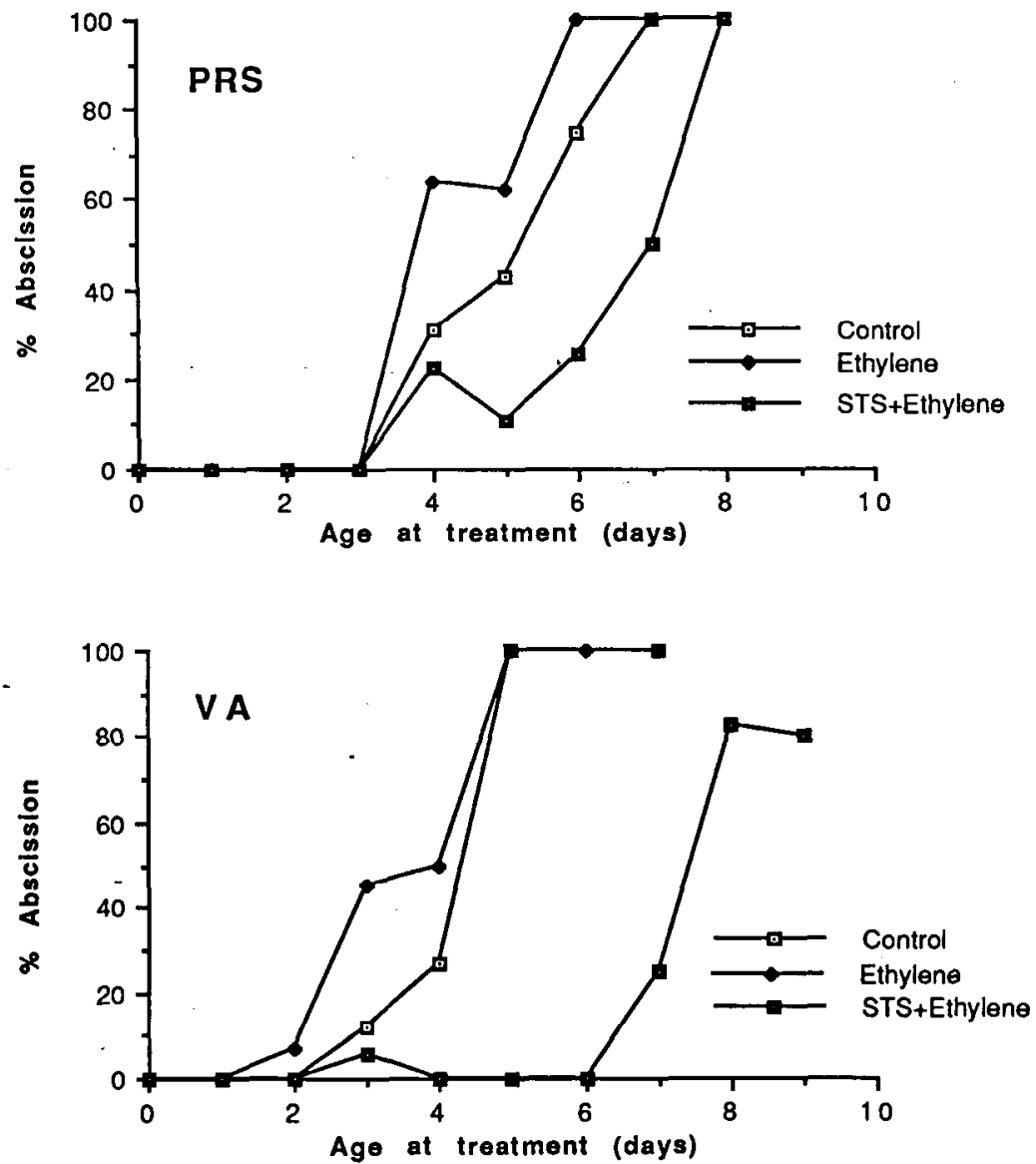

Fig. 2. Effects of ethylene $\left(0.5 \mu \mathrm{l} \cdot \mathrm{liter}^{-1}\right.$ for $1 \mathrm{hr}$ at $\left.21 \mathrm{C}\right)$, STS ( $1 \mathrm{~mm}$ at anthesis), and floret age at time of ethylene exposure on petal abscission after 1 day for plants of regal pelargonium cultivars PRS and VA. In the analysis of variance, treatment was significant at $P<0.05$, while age and the treatment $\times$ age interaction were significant at $P<0.01$.

a solar monitor and a quantum sensor (Model LI-1776; LI-COR, Lincoln, Neb.). Ethylene was measured-using a gas chromatograph with a flame ionization detector and a column of activated alumina (Model 5840A HewlettPackard Co., Palo Alto, Calif.).

Simulated consumer environment. Based on recommendations by Conover et al. (1981), a simulated consumer environment (SCE) was maintained at $21 \pm 1 \mathrm{C}, 50 \% \pm 15 \% \mathrm{RH}$, miculite. The floral initiation treatment was 38 days at $10 \pm 2 \mathrm{C}$ in a greenhouse with incandescent lighting of $10 \mu \mathrm{mol} \cdot \mathrm{s}^{-1}-\mathrm{m}^{-2}$ from 1800 to $2400 \mathrm{HR}$. Forcing followed under 21C day (ventilation setpoint) and 16C night (heat setpoint) conditions with the same incandescent lighting. Plants were fertilized weekly with $200 \mathrm{pg} \mathrm{N} /$ liter using a soluble 15N-7P-14.1K fertilizer (Peters Fertilizer Products, Fogelsville, Pa.). For STS treatments, a foliar spray of $1 \mathrm{~mm}$ STS solution, as suggested by Cameron et al. (1981), plus one drop of a surfactant (polyoxyethylene sorbitan, Sigma Chemical Co., St. Louis) per $500 \mathrm{ml}$ was applied until runoff at time of anthesis of the first floret on each plant (defined as the stage when the stigmata and anthers were visible). Preliminary research indicated that $1 \mathrm{~mm}$ STS was the most effective concentration (data not shown). Controls were sprayed with deionized water plus the surfactant.

Florets were removed from harvested inflorescences to leave three florets per inflorescence that had been open for 1 or 2 days. Floret age was estimated by the appearances of the stigmata and anthers; experience had shown that the stigmatic lobes began to separate and the anthers to discolor at 3 days postanthesis. The peduncles were trimmed to $5 \mathrm{~cm}$ and immediately inserted into $35-\mathrm{ml}$ vials containing deionized water. The inflorescences were treated with ethylene for $1 \mathrm{hr}$ at $21 \pm 1 \mathrm{C}$ by placing them in an 8-liter chamber and injecting ethylene to achieve $0.5 \mu \mathrm{l} \cdot$ liter $^{-1}$. Preliminary research indicated that this dosage of ethylene resulted in different responses among regal pelargonium cultivars. Rapid mixing of gases within the chamber was ensured by using a modified magnetic stirring bar and stirrer. Controls were treated identically, except air was injected into the treatment chamber.

After treatment, inflorescences were arranged in a completely randomized design in a controlled-environment room at $21 \pm 2 \mathrm{C}$, with light levels of $30 \mu \mathrm{mol} \cdot \mathrm{s}^{-1} \cdot \mathrm{m}^{-2}$ provided by cool-white fluorescent lamps from 0800 to $2000 \mathrm{HR}$. Petal retention was evaluated after $24 \mathrm{hr}$. The experiment was a six cultivar $\times$ two STS $\times$ two ethylene treatment factorial design. At least eight inflorescences per cultivar per treatment were used. Analysis of variance was performed on transformed (arcsin of square root) percentage data.

Effects of floret age, ethylene, and STS. PRS and VA were selected for further investigation of ethylene sensitivity because they represented extremes (low and high, respectively) in floret longevity. Rooted and cooled cuttings were transplanted into 1.5-liter azalea pots using a medium of sphagnum peat, perlite, and vermiculite (Fafard Peat Moss Co., New Brunswick, Canada). Forcing was at $24 \pm 2 \mathrm{C}$ day and $18 \pm 1 \mathrm{C}$ night and $70 \% \pm 20 \% \mathrm{RH}$. Average PPF was $315 \mu \mathrm{mol} \cdot \mathrm{s}^{-1} \cdot \mathrm{m}^{-2}$ provided by cool-white fluorescent lamps from 0600 to $2400 \mathrm{HR}$. About $4 \mathrm{~g}$ of 14N-6.2P-11.6K (Osmocote, Sierra Chemical Co., Milpitas, Calif.) per pot were applied to the surface of the medium 1 week after potting. Plants were fertil- 


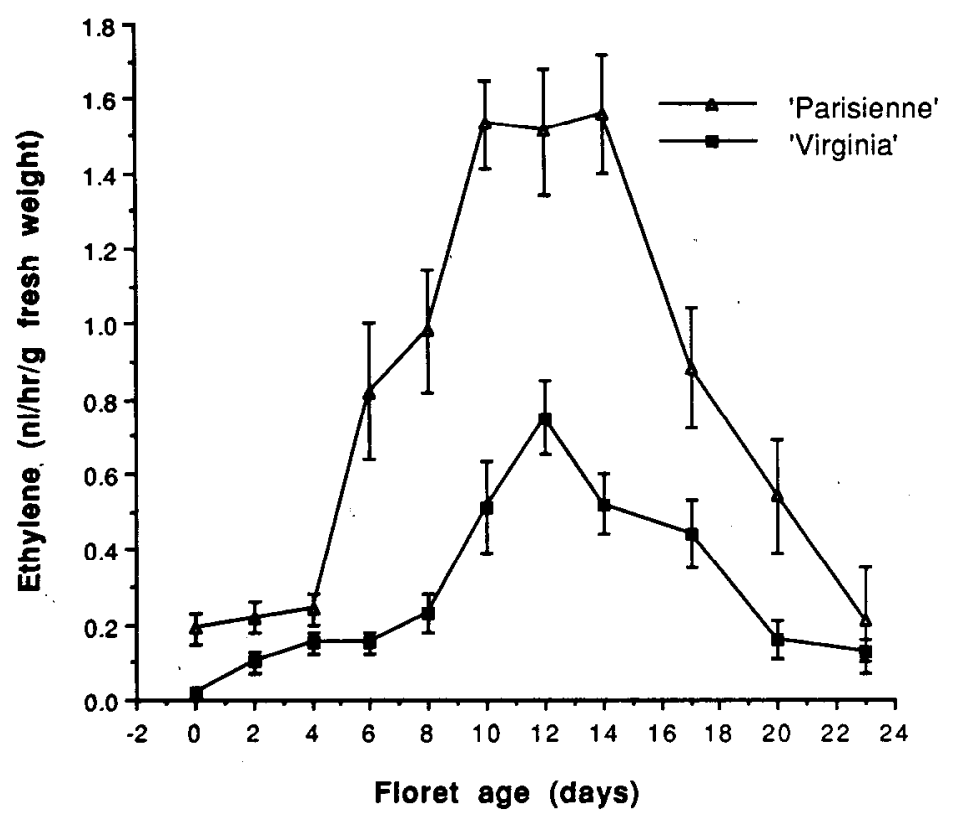

Fig. 3. Relationship between floret age and ethylene production at $30 \mathrm{C}$ by excised gynoecium and receptacle tissues of regal pelargonium cultivars PRS and VA. Vertical bars indicate SE.

Table 2. Ethylene and $\mathrm{CO}_{2}$ production by regal pelargonium cultivar PRS gynoecium and receptacle tissues excised at various floret ages, with the base of the receptacle placed in $0.2 \mathrm{ml}$ water or $1 \mathrm{mM}$ ACC. (Numbers shown are means \pm SE.)

\begin{tabular}{cccc}
\hline $\begin{array}{c}\text { Floret age } \\
\text { (days) }\end{array}$ & Treatment & $\begin{array}{c}\text { Ethylene } \\
\left(\mathrm{nl} \cdot \mathrm{hr}-1 \cdot \mathrm{g}^{-1} \text { fresh wt) }\right.\end{array}$ & $\begin{array}{c}\mathrm{CO}_{2} \\
\left(\mu \mathrm{l} \cdot \mathrm{hr}^{-1} \cdot \mathrm{g}^{-1} \text { fresh wt) }\right.\end{array}$ \\
\hline 0 & Control & $0.6 \pm 0.1$ & 430 \\
& ACC & $15.8 \pm 6.6$ & -- \\
7 & Control & $0.7 \pm 0.2$ & 340 \\
& ACC & $59.6 \pm 37.7$ & 340 \\
11 & Control & $0.5 \pm 0.2$ & $\cdots$ \\
& ACC & $133 \pm 2.0$ & 320 \\
\hline
\end{tabular}

ized weekly with $150 \mu \mathrm{N}$ /liter, alternating soluble $15 \mathrm{~N}-7 \mathrm{P}-14.1 \mathrm{~K}$ and soluble $15 \mathrm{~N}-0 \mathrm{P}-$ 12.4K. Some plants were treated with STS as described above. Each floret was labeled at anthesis to record its chronological age; by also recording the date of senescence or abscission, we were able to calculate longevity for each floret.

About 2 weeks after first anthesis, some plants were treated with $0.5 \mu 1$ ethylene/liter for $1 \mathrm{hr}$ in darkness at $21 \pm 1 \mathrm{C}$. Ethylene was added in a flow-through system that provided 10 air exchanges/hr in a sealed controlled-environment chamber. The uniformity of ethylene concentration within the chamber was verified by sampling at $15 \mathrm{~min}$ intervals at six locations in the chamber. Ethylene accumulation (from endogenous sources) in the control chamber was prevented by placing $\mathrm{KMnO}_{4}$ in the chamber. After treatment, plants were placed in the SCE for 3 weeks, and the florets were evaluated daily for petal abscission. Abscission was considered to have occurred if more than one-half the petals on a given floret had abscised. Six plants were used per treatment (control, ethylene, and STS + ethylene) per cultivar. The experiment was a two cultivar $\times$ three treatment factorial design and was analyzed by regression, using age as a continuous variable.
Endogenous ethylene production by excised gynoecium and receptacle tissue. Rooted and cooled cuttings of PRS and VA were potted as described in the floret age experiment. Fifteen plants per cultivar were arranged in a completely randomized design in a controlled-environment chamber. Forcing was at $18 \pm 1 \mathrm{C}$ day and $13 \pm 1 \mathrm{C}$ night. The average PPF was $368 \mu \mathrm{mol} \cdot \mathrm{s}^{-1} \cdot \mathrm{m}^{-2}$ provided by cool-white fluorescent and incandescent lamps from 0600 to $2400 \mathrm{HR}$; the incandescent lamps provided $12.7 \%$ of the total input wattage. Relative humidity was $70 \% \pm 20 \%$. Fertilization was the same as in the previous experiment. Two plants per cultivar were treated with STS as described above.

To measure ethylene evolution, florets were harvested at various ages after anthesis. The gynoecium and receptacle tissues plus the bases of the sepals and petals were excised and placed in $5-\mathrm{ml}$ vials. Filter paper $\left(3 \mathrm{~cm}^{2}\right)$, moistened with distilled and deionized water, was placed in the vials to prevent tissue desiccation. Although there was no measurable wound ethylene response, preliminary research indicated that respiration rates (as measured by $\mathrm{CO}_{2}$ evolution) were more stable after a 4-hr equilibration period at $25 \pm$ $1 \mathrm{C}$ and that neither $\mathrm{CO}_{2}$ accumulation in the sealed vials nor exposure to light affected ethylene production. Therefore, $4 \mathrm{hr}$ after excision, the vials were flushed with air and sealed for $15 \mathrm{~min} ; \mathrm{CO}_{2}$ was then measured by gas chromatography. The vials were reflushed, resealed, and placed in an incubator in darkness at $30 \pm 1 \mathrm{C}$ for $10 \mathrm{hr}$, and ethylene was measured. At least three florets of each age per cultivar were included in each of four experiments. The effects of 1-aminocyclopropane-1-carboxylic acid (ACC) on production of ethylene by the gynoecium and receptacle tissues were determined with two PRS florets of each age by applying $0.2 \mathrm{ml}$ of $1 \mathrm{~mm}$ ACC to the base of the gynoecium and receptacle tissues after the equilibration period. Longevity of florets remaining on the plants was recorded.

Cultivar comparison. One- to 2-day-old florets of all cultivars, except VA, responded to ethylene by rapid petal abscission; the amount of abscission varied with cultivar (Fig. 1). No wilting was observed preceding petal abscission.

Effects of floret age, ethylene, and STS. When plants of PRS and VA bearing florets of various ages were exposed to ethylene at $0.5 \mu \mathrm{l} \cdot$ liter $^{-1}$ for $1 \mathrm{hr}$, substantial abscission occurred only in florets 3 days old or older (Fig. 2). This accounts for the absent or minimal ethylene response observed in 1- to 2day-old detached florets of these two cultivars (Fig. 1). The increase in ethylene sensitivity with age is similar to that observed in climacteric fruit and in some other flowers, such as carnations (Barden and Hanan, 1972), kalanchoe (Marousky and Harbough, 1979), and hibiscus (Woodson et al., 1985). VA developed ethylene sensitivity earlier than PRS; $45 \%$ of 3-day-old VA florets abscised (four times the control amount), but none of the 3-day-old PRS flowers did (Fig. 2).

Florets from plants treated with STS were less responsive to ethylene at any age (Fig. 2). In PRS, STS not only reduced abscission of open florets (Fig. 2), but also increased the longevity of buds that reached anthesis in the SCE by more than $50 \%$ (Table 1). STS-treated PRS plants had a noticeably superior floral display compared to control and ethylene-treated plants because of the greater number of intact florets. In VA, on the other hand, neither ethylene nor STS had any effect on longevity of florets that were still at the bud stage when ethylene was added. In regal pelargoniums, some abscission still occurred in response to ethylene in STS-treated plants (Fig. 2). In seed geraniums, STS treatment almost completely suppressed abscission (Cameron and Reid, 1983); however, in that experiment, plants were not challenged with ethylene. When regal pelargonium plants were grown in a growth chamber (as described for the experiment "Endogenous ethylene production by excised gynoecium and receptacle tissue"), treated with STS, but not ethylene, and the longevity in the growth chamber recorded, longevity was increased by more than $50 \%$ in PRS and by $175 \%$ in VA (Deneke, 1988).

Longevity (later abscission and wilting) of the open florets that did not immediately re- 
spond to ethylene was not affected by ethylene (Table 1). Florets that reached anthesis in the SCE after the ethylene treatment (i.e., which were buds at the time of ethylene treatment) had longevity equal to or longer than florets on untreated plants, demonstrating the relative insensitivity of buds to ethylene (Table 1). The increased longevity of buds from ethylene-treated PRS plants could have been caused by the abscission of older florets, freeing resources to support developing buds.

The overall quality of the plants grown for the floret age experiment (Fig. 2) was worse than that in the cultivar comparison (Fig. 1); leaf chlorosis was greater and floret longevity was reduced. Except for temperature, all of the environmental variables measured during production were similar to those in other experiments producing plants with noticeably better quality. The possibility that higher temperatures during production reduces postharvest quality deserves further investigation.

The sensitivity of regal pelargonium florets to ethylene is remarkable. In a classification of ethylene sensitivity of flowering plants, Woltering (1987) defined the most sensitive of eight classes as those showing $>66 \%$ abscission or senescence in response to $3 \mu 1$ ethylene/liter for $24 \mathrm{hr}$, giving a dose of $72 \mu \mathrm{l} \cdot \mathrm{liter}^{-1} \cdot \mathrm{hr}^{-1}$ [where the dose is the product of the concentration and theduration (Barden and Hanan, 1973)]. Since our dose was only $0.5 \mu \mathrm{l} \cdot \mathrm{liter}^{-1} \cdot \mathrm{hr}^{-1}$, regal pelargoniums clearly rank among the species most responsive to ethylene. The response was also very rapid; although data were not collected until $24 \mathrm{hr}$ after the ethylene treatments, petal abscission was observed as early as $2 \mathrm{hr}$ after the initiation of the ethylene treatment. In a related species, Geranium robertianum, petal abscission began $2.25 \mathrm{hr}$ after the ethylene treatment began (Sexton et al., 1983). Senescence or abscission of flowers in other species takes considerably longer, e.g., 4.5 $\mathrm{hr}$ for tobacco pedicel abscission (Lieberman et al., 1982) and $6 \mathrm{hr}$ for carnation wilting (Mayak et al., 1977).

Endogenous ethylene production by excised gynoecium and receptacle tissue. Preliminary studies indicated that ethylene production by detached inflorescences or florets was too low to measure, perhaps because of the relatively large container volume necessary to enclose a floret with a low mass. In dissected florets, the petals showed very low rates of ethylene production, $<0.2$ $\mathrm{nl} \cdot \mathrm{hr}^{-1} \cdot \mathrm{g}^{-1}$ fresh weight. The excised $\mathrm{gy}-$ noecium and receptacle tissues of both PRS and VA showed a climacteric-like pattern in ethylene production as floret age increased (Fig. 3). Ethylene production by PRS began to increase dramatically $\approx 4$ days earlier than VA and peaked-at $1.5 \mathrm{nl} \cdot \mathrm{hr}^{-1} \cdot \mathrm{g}^{-1}$ fresh weight after 14 days; ethylene production by VA peaked after 12 days at $0.8 \mathrm{nl} \cdot \mathrm{hr}^{-1} \cdot \mathrm{g}^{-1}$ fresh weight. The age at which $50 \%$ petal abscission occurred was $16 \pm 1$ days (mean $\pm \mathrm{SE}$ ) for PRS and $21 \pm 1$ days for VA. PRS florets produced considerably greater cumulative amounts of ethylene than VA florets.
This climacteric-like pattern in ethylene production was not found in seed geraniums (Pelargonium $\times$ hortorum) (Armitage et al., 1980), which abscise petals in response to either pollination or ethylene (Armitage et al., 1980; Cameron and Reid, 1983; Wallner et al., 1979).

Rates of ethylene production by regal pelargoniums were low, compared with levels reported for flowers of other species [e.g., $3400 \mathrm{nl} \cdot \mathrm{g}^{-1} \cdot \mathrm{hr}^{-1}$ from Vanda 'Miss Agness Joaquim' (Akamine, 1963), $100 \mathrm{nl} \cdot \mathrm{g}^{-1}-\mathrm{hr}^{-1}$ from carnations (Bufler et al., 1980), and 4 to $16 \mathrm{nl} \cdot \mathrm{g}^{-1} \cdot \mathrm{hr}^{-1}$ from zonal geraniums (Miranda, 1981)], particularly since ethylene production may have been enhanced by excision. However, the sensitivity of regal pelargonium florets to exogenous ethylene and the pattern of endogenous ethylene production indicate that the relatively low levels of endogenous ethylene probably regulate natural petal abscission.

Exogenous ACC increased ethylene production 20 to 200 fold in PRS florets, including those that had just reached anthesis (Table 2). ACC also enhanced ethylene production in morning glory (Ipomoea tricolor Cav.) flowers, regardless of the physiological age of the tissues (Konze et al., 1980), indicating the presence of constitutive ethylene-forming enzyme activity at anthesis. The synthesis of ACC may, therefore, be a limiting step in ethylene production in these flowers.

Rates of $\mathrm{CO}_{2}$ production by the gynoecium and receptacle tissues of PRS varied slightly and then declined, coinciding with the declines in ethylene production (Table 2); PRS and VA showed similar patterns of respiration (data not shown). These declines in ethylene and $\mathrm{CO}_{2}$ production reflected the progressive senescence of the aging florets and overall decline in metabolic activities. There was no peak in $\mathrm{CO}$, production associated with the peak in ethylene production.

What accounts for the superior postproduction quality of VA plants? We found that VA florets had $\approx 50 \%$ greater longevity than those of PRS (Table 1). VA was at least as responsive as PRS to ethylene, and STS had a more dramatic effect on VA (Fig. 2). We propose that the superior postproduction quality of VA is a result of lower endogenous ethylene production (Fig. 3), permitting increased floret longevity and a better floral display compared with PRS. In the event of an ethylene exposure, florets of both cultivars older than 3 days would be lost.

Rapid petal abscission has often been observed after shipping regal pelargoniums in flower (J.R. Oglevee, personal communication). Shipping may increase endogenous ethylene production or expose plants to exogenous ethylene. Abscission during shipping could be reduced by shipping plants at the bud stage and/or by use of STS sprays.

\section{Literature Cited}

Agnew, N.H., M.L. Albrecht, and R.K. Kimmins. 1985. Reducing corolla abscission of
Streptocarpus $\times$ hybridus under simulated shipping conditions with silver thiosulfate. HortScience 20:118-119.

Akamine, E.K. 1963. Ethylene production in fading Vanda orchid blossoms. Science 140:12171218

Armitage, A.M., R. Heins, S. Dean, and W. Carlson. 1980. Factors influencing flower petal abscission in-the seed-propagated geranium. J. Amer. Soc. Hort. Sci. 105:62-564.

Barden, L.E. and J.J. Hanan. 1972. Effect of ethylene on carnation keeping life. J. Amer. Soc. Hort. Sci. 97:785-788.

Beyer, E.M., Jr. 1976. Silver ion: A potent antiethylene agent in cucumber and tomato. HortScience 11:195-196.

Bufler, G., Y. Mor, M.S. Reid, and S.F. Yang. 1980. Changes in 1-aminocyclopropane-1carboxylic acid content in cut carnation flowers in relation to their senescence. Planta 150:439-

Cameron, A.C. and M.S. Reid. 1981. The use of silver thiosulfate anionic complex as a foliar spray to prevent flower abscission of zygocactus. HortScience 16:761-762.

Cameron, A.C. and M.S. Reid. 1983. Use of silver thiosulfate to prevent flower abscission from potted plants. Scientia Hort. 19:373-378.

Cameron, A.C. M.S. Reid, and G. W. Hickman. 1981. Using STS to prevent flower shattering in potted flowering plants-Progress report Flower \& Nursery Rpt. Fall 1981. Univ. of California Coop. Ext. p. 1-3.

Conover, C., R.D. Heins, and G. Staby. 1981. Postharvest-handling of container-grown plants. Florists Rev. 168(4634):20, 22

Deneke, C.F. 1988. The post-harvest quality of Pelargonium $\times$ domesticum L.H. Bailey. $\mathrm{PhD}$ Diss., Penn State Univ., University Park.

Halevy, A.H. 1986. Pollination-induced corolla senescence. Acta Hort. 181:25-31.

Konze, J.R., J.F. Jones, T. Boller, and H. Kende. 1980. Effect of 1-aminocyclopropane-1-carboxylic acid on the production of ethylene in senescing flowers of Ipomoea tricolor Cav. Plant Physiol. 66:566-571.

Lieberman, S.J., J.G. Valdovinos, and T.E. Jensen. 1982. Ultrastructural localization of cellulase in abscission cells of tobacco flowe pedicels. Bot. Gaz. 143:32-40

Marousky, F.J. and B.K. Harbaugh. 1979. Ethylene-induced floret sleepiness in Kalanchoe blossfeldiana Poelln. HortScience 14:505-507.

Mayak, S., Y. Vaadia, and D.R. Dilley. 1977. Regulation of senescence in carnation (Dianthus caryophyllus) by ethylene. Plant Physiol. 59:591-593.

Miranda, R.M. 1981. Studies on petal abscission in hybrid geranium. PhD Diss., Michigan State Univ., East Lansing.

Nichols, R. 1984. Ethylene and flower senescence, p. 1-10. In: Y. Fuchs and E. Chalutz (eds.). Ethylene: Biochemical, physiological, and applied aspects. Martinus NijGoff/DL W. Junk Publishing, The Hague, Netherlands.

Sexton, R., W.A. Struthers, and L.N. Lewis. 1983 Some observations on the very rapid abscission of the petals of Geranium robertianum L. Protoplasma 116:179-186.

Wallner, S., R. Kassalen, J. Burgoon, and R. Craig. 1979. Pollination, ethylene production and shattering in geraniums. HortScience 14(Suppl.):446.

Woltering, E.J. 1987. Effects of ethylene on ornamental pot plants: A classification. Scientia Hort. 31:183-294.

Woodson, W.R.. S.H. Hanchey, and D.N. Chisholm. 1985. Role of ethylene in senescence of isolated hibiscus petals. plant Physiol. 79:679683. 